Mini review

\title{
Recent Progress in Electrochemical Detection of Beta-amyloid Peptides and Their Aggregates
}

\author{
Ning Xia ${ }^{1, *}$, Yong Chang ${ }^{1}$, Yuanqiang Hao ${ }^{1,2}$, \\ ${ }^{1}$ Henan Province of Key Laboratory of New Optoelectronic Functional Materials, College of \\ Chemistry and Chemical Engineering, Anyang Normal University, Anyang, Henan 455000, People's \\ Republic of China \\ ${ }^{2}$ Henan Key Laboratory of Biomolecular Recognition and Sensing, College of Chemistry and \\ Chemical Engineering, Shangqiu Normal University, Shangqiu, Henan 476000, People's Republic of \\ China \\ *E-mail: xianing82414@csu.edu.cn
}

doi: $10.20964 / 2017.07 .24$

Received: 1 April 2017 / Accepted: 30 April 2017 / Published: 12 June 2017

Beta-amyloid $(\mathrm{A} \beta)$ peptides and their aggregates are regarded as the promising biomarkers for Alzheimer's disease (AD) diagnosis. In this work, we focused on the recent progress in the development of electrochemical methods for the detection of A $\beta$ monomers and their aggregates. In particular, the receptors for the selective capture of $A \beta$ monomers and oligomers were summarized.

Keywords: Alzheimer's disease; beta-amyloid; electrochemical detection; bioreceptors

\section{$\underline{\text { FULL TEXT }}$}

(C) 2017 The Authors. Published by ESG (www.electrochemsci.org). This article is an open access article distributed under the terms and conditions of the Creative Commons Attribution license (http://creativecommons.org/licenses/by/4.0/). 